\title{
Studi Etnomedisin Tanaman Berkhasiat Obat Hipertensi di Kecamatan Poleang Tenggara Kabupaten Bombana Sulawesi Tenggara
}

\author{
Selpirahmawati Saranani*, Himaniarwati, Wa Ode Yuliastri, Muhammad Isrul, Aulia \\ agusmin \\ Program Studi Farmasi, Universitas Mandala Waluya
}

\begin{abstract}
ABSTRAK
Etnomedisin sebagai salah satu cara yang dapat digunakan untuk menelusuri pemanfaatan tumbuhan berkhasiat obat dapat menjadi langkah awal untuk mengembangkan obat baru. Hipertensi menjadi salah penyakit tidak menular yang masih mengancam kesehatan manusia. Pencegahan dan pengelolaan hipertensi adalah tantangan kesehatan masyarakat utama di seluruh dunia. Tekanan darah tinggi yang tidak terkontrol dapat menyebabkan harapan hidup yang lebih pendek dan morbiditas yang lebih tinggi karena risiko tinggi komplikasi kardiovaskular seperti penyakit jantung koroner (yang menyebabkan serangan jantung) dan stroke, gagal jantung kongestif, ketidakteraturan irama jantung, dan gagal ginjal.Tujuan dari penelitian ini adalah untuk mengetahui jenis tanaman yang digunakan sebagai obat untuk hipertensi, mengetahui bagian tanaman yang digunakan sebagai obat hipertensi dan bagaimana cara pengolahan tanaman obat yang digunakan untuk mengobati hipertensi di Kecamatan Poleang Tenggara Kabupaten Bombana. Jenis penelitian ini adalah penelitian deskriptif
\end{abstract}

dengan analisis data menggunakan pendekatan metode kualitatif dengan tehnik snowball sampling dan analisi data secara kuantitatif. Data penggunaan tanaman obat telah dikumpulkan dengan menggunakan wawancara langsung kepada pengobat tradisional atau battra, dan informan lainnya, yang terdiri dari 10 responden. Informasi yang didapatkan berupa nama tanaman obat, nama daerah, bagian tanaman yang digunakan, dan cara pengolahannya. Berdasarkan hasil wawancara yang telah dilakukan, terdapat 20 spesies tanaman obat yang digunakan untuk mengobati hipertensi. Bagian tanaman yang digunakan antara lain daun, buah, biji rimpang dan herba. Cara pengolahann tanaman yang digunakan adalah dengan cara direbus, diseduh, ditumbuk (diblender), dan dikunyah. Famili tanaman obat yang dimanfaatkan adalah famili acanthaceae, asteraceae, moraceae.

Kata Kunci : Etnomedisin, Hipertensi, Tanaman Obat, Obat Tradisional, Bombana

\begin{abstract}
Ethnomedicine as a method that can be used to explore medicinal plants can be first step to develop new drugs. Hypertension is a non-communicable disease that still threatens human health. Prevention and management of hypertension is a major public health challenge worldwide. Uncontrolled high blood pressure can lead to shorter life expectancy and higher morbidity due to risk of cardiovascular complications such as coronary heart disease (which causes heart attack) and stroke, congestive heart failure, heart irregularities, and kidney failure. The purpose this study was determine the types of plants used as drugs for hypertension, to determine parts of plants used as hypertension drugs, and how

quantitative method. Data has been collected using direct interviews with traditional healers or battras, and other informants, consisting of 10 respondents. The information obtained is in the form of the name of the medicinal plant, the name of the area, the part of the plant used, and the method of processing it. Based on the results of interviews that have been conducted, there are 20 species of medicinal plants used to treat hypertension. The plant parts used include leaves, fruit, seeds, rhizomes and herbs. The method of processing the plants used is by searching, brewing, pounding (blending), and chewing. The medicinal plant families used were the Acanthaceae, Asteraceae, and Moraceae families.
\end{abstract} to process medicinal plants used hypertension treatment in Poleang Tenggara District, Bombana Regency. This type of research is descriptive research with data analysis used qualitative approach with snowball sampling technique and
Keywords: Ethnomedicin, Hypertension, Medicinal Plants, Traditional Medicine, Bombana

\author{
Penulis Korespondensi : \\ Selpirahmawati Saranani \\ Prodi Farmasi, Universitas Mandala Waluya \\ E-mail : firsel1012@gmail.com
}

Informasi Artikel

Submitted Accepted Published
: 13 Mei 2021

: 29 Juni 2021

: 30 Juni 2021 


\section{PENDAHULUAN}

Indonesia dengan karkteristik negara archipleago serta dihuni berbagai etnik suku bangsa dengan masingmasing budayanya yang khas merupakan sebuah keuntungan yang istimewa. Setiap etnik menyimpan kearifan lokal yang khas sesuai dengan budaya dan adat istiadat serta tradisi turun-temurun yang diwarisi dari pendahulunya. Termasuk bagaimana setiap etnik memaknai konsep sakit, sehat dan keragaman jenis tumbuhan yang digunakan sebagai Obat Tradisional (OT) untuk menjaga kesehatan terbentuk melalui suatu proses sosialisasi yang secara turun-temurun dipercaya dan diyakini kebenarannya (Moelyono, 2014).

Dalam era globalisasi saat ini, pengobatan tradisonal masih berfungsi dalam kehidupan masyarakat Indonesia meskipun pengobatan secara modern telah diterapkan, alasan masyarakat masih menggunakan pengobatan tradisonal dikarenakan masih adanya kepercayaan masyarakat tertentu akan pengetahuan yang berasal dari nenek moyang yang diwariskan secara turuntemurun dengan menggunakan bahanbahan dari alam maupun melalui jasa seseorang yang dipercaya dapat mengobati (Mujahid et al., 2019). Menurut Sapei et al., (2011) setiap suku/etnis di berbagai daerah di Indonesia memiliki pengetahuan yang cukup baik mengenai keanekaragaman jenis tumbuhan berguna yang tumbuh di sekitar pemukiman mereka.

Penelitian pemanfaatan tumbuhan sebagai bahan obat sejalan dengan peradaban manusia dan terus dikembangkan hingga saat ini. Berbagai metode yang digunakan dalam penelitian tumbuhan obat antara lain melalui pendekatan etnobotani atau etnomedisin, skrining senyawa fitokimia, maupun pendekatan taksonomi. Pendekatan etnomedisin merupakan cara penelitian yang efektif dari segi waktu dan biaya untuk mendapatkan senyawa obat baru (Fabricant \& Farnsworth, 2001). Hal tersebut mengakibatkan penelitian etnomedisin terus dilakukan diberbagai daerah termasuk Indonesia. Etnomedisin merupakan studi tentang presepsi dan konsepsi masyarakat lokal dalam memahami kesehatan atau studi yang mempelajari sistem medis etnis tradisional (Bhasin, 2007; Daval, 2009) yang dilakukan melalui pendekatan emik dan pendekatan ilmiah (Walujo, 2009). Penelitian pemanfaatan tumbuhan obat pada berbagai masyarakat (cross-cultural studies) dapat digunakan untuk menemukan obat maupun senyawa bioaktif.

Etnomedisin merupakan suatu tahapan penting dalam menskrining, memilih dan mengembangkan obat baru yang berasal dari tumbuhan. Para pengobat tradisional dari berbagai kelompok etnis menjaga dan 
merahasiakan

pengetahuan

pengobatannya karena mereka meyakini bahwa membagi pengetahuannya kepada orang lain akan mengakibatkan kehilangan

kemampuan penyembuhannya. Oleh karena itu, engetahuan pengobatan menggunakantumbuhan biasanya diwariskan secara turun-temurun. Praktek pengobatan tradisional tersebut umumnya tidak terdokumentasi karena diwariskan dari satu generasi ke generasi berikutnya dari mulut ke mulut, sehingga banyak data pengetahuan tradisional mengenai tumbuhan obat yang hilang (Paul et al., 2013). Degradasi habitat, hilangnya ekosistem tumbuhan, dan lunturnya budaya juga mengakibatkan terancamnya keberlangsungan praktek pengobatan secara tradisional (Van Wyk \& Ben-Erik, 2004). Karenanya, eksplorasi sistematik terhadap kekayaan budaya pengobatan tradisional menjadi prioritas dalam penemuan alternatif pengobatan penyakit seperti hipertensi.

Besarnya kontribusi senyawa alam terhadap penemuan obat modern tidak terlepas dari pendekatan yang dilakukan dalam pencariannya. Pendekatan yang sangat berarti adalah kajian etnobotani, yaitu kajian berdasarkan penggunaan tanaman tertentu oleh masyarakat sebagai obat atau lebih umum disebut tanaman obat tradisional. Pendekatan ini minimalnya memberikan rasa aman atau tidak takut keracunan karena bahan- bahan obat yang digunakan berasal dari tanaman yang pernah dikonsumsi sebelumnya (Sahidin, 2019). Berdasarkan laporan Melamba (2019) Orang Moronene sebagai salah satu etnis dominan di kabupaten Bombana memiliki Pengetahuan akan berbagai jenis etnobotani, serta kemampuan mereka menggunakan maupun keterampilan yang mereka miliki dalam meracik apa yang disediakan oleh alam. Sistem pengobatan etnomedisin sangat membantu bagi perkembangan kesehatan dalam bertahan hidup. Orang Moronene yang bermukim di wilayah Sulawesi Tenggara memiliki ragam kebiasaan dalam menentukan tempat pelayanan kesehatan. Masyarakat yang tinggal di kampung atau pedesaan penentuan pengobatan didasarkan pada keyakinan yang telah dianut secara turun temurun. Sando atau tabib merupakan rujukan utama mereka yang bekerja sebagai battra.

saat ini minat masyarakat berobat menggunakan pengobatan tradisional sangat meningkat, beberapa alasan seperti adanya kecocokan dengan obat tradisional yang digunakan, belum sembuhnya pengobatan konvensional yang di jalani dan motivasi ingin cepat sembuh yang tinggi pada pasien hipertensi mendorong pasien hipertensi berobat dan menggunakan pengobatan tradisional (Gusti et al., 2018). Sehingga menelusuri tanaman berkhasiat obat yang sering digunakan oleh masyarakat untuk 
mengobati hipertensi dapat membantu mengungkap kekayaan kearifan lokal untuk menemukan obat maupun senyawa bioaktif yang dimiliki oleh tanaman berkhasiat obat tersebut.

Hipertensi menjadi ancaman kesehatan masyarakat karena potensinya yang mampu mengakibatkan kondisi komplikasi seperti stroke, penyakit jantung koroner, dan gagal ginjal. Hipertensi menurut data WHO tahun 2015 menunjukkan sekitar 1,13 miliar orang di dunia menderita hipertensi. Jumlah penderita hipertensi di dunia terus meningkat setiap tahunnya. Diperkirakan pada 2025 terdapat 1,5 miliar orang yang terkena hipertensi dengan pasien meninggal akibat hipertensi dan komplikasi sekitar 9,4 juta orang (Purwono et al., 2020). Hasil Riskesdas tahun 2018 menunjukkan angka prevalensi hipertensi pada penduduk >18 tahun berdasarkan pengukuran secara nasional sebesar 34,11\%, lebih tinggi dibandingkan prevalensi tahun 2013 sebesar 25,8\% (Riset Kesehatan Dasar, 2018). Dari data tersebut prevalensi hipertensi berdasarkan diagnosis dokter pada penduduk umur $\geq 18$ tahun menurut provinsi, prevalensi hipertensi di sulawesi tenggara sebesar 29,75\%. Hipertensi merupakan salah satu jenis penyakit yang dikenal dalam sistem pengobatan orang morenene dalam konsepsi etnomedisin masyarakat Bombana yang disebut sebagai penyakit darah tinggi.

Kecamatan Poleng Tenggara kabupaten Bombana merupakan salah satu wilayah di kabupaten Bombana yang dihuni oleh etnis Moronene, bugis, bajo dan beberapa etnis lainnya. Tradisi pemanfaatan tumbuhan obat di Kecamatan Poleang Tenggara Kabupaten Bombana disebabkan minimnya fasilitas kesehatan dimana hanya terdapat satu puskesmas dalam satu kecamatan, dengan jarak tempuh yang jauh antar satu desa dengan desa lainnya. Oleh karena itu, masyarakat lebih memilih memanfaatkan tumbuhan yang mudah di dapatkan. Tanaman tersebut dikenal sebagai tanaman obat yang turun temurun di wariskan oleh nenek moyang mereka dalam mengobati berbagai jenis penyakit pada masyarakat di desa di Kecamatan Poleang Tenggara Kabupaten Bombana. Hal yang sama pernah dilaporkan oleh Melamba (2019) bahwa masyarakat yang tinggal di kampung atau pedesaan dalam menentukan pengobatan didasarkan pada keyakinan yang telah dianut secara turun temurun. Sando atau tabib adalah salah satu yang menjadi pilihan utama mereka. Sando merupakan pengertian dari pengobat tradisional atau battra. Sebelum dibukanya Rumah Sakit Umum di Kabupaten Bombana maupun fasilitas jalan yang menghubungkan ibu kota kabupaten maupun provinsi. Biasanya jika masyarakat Moronene merasakan sakit 
menurut pengalaman empiris ditangani terlebih dahulu dengan pengobatan tradisional (Melamba, 2019).

Berdasarkan uraian diatas, dengan besarnya kontribusi dan potensi dari studi etnomedisin maka penelitian ini dilakukan dengan tujuan untuk mengetahui jenis tanaman yang dapat dijadikan obat hipertensi, mengetahui bagian tanaman yang dijadikan obat hipertensi dan bagaimana cara pengolahannya sebagai obat tradisional khususnya di Kecamatan Poleang Tenggara Kabupaten Bombana.

\section{METODE PENELITIAN}

\section{Lokasi Penelitian}

Penelitian ini dilaksanakan di Kecamatan Poleang Tenggara Kabupaten Bombana Provinsi Sulawesi Tenggara . Tahapan penelitian meliputi 4 tahap yaitu studi pendahuluan, wawancara, observasi, dan dokumentasi yang dilakukan di Desa Larete, Desa Terapung, Desa Lemo, Desa Rambaha, dan Desa Lamoare.

\section{Keadaan Umum Lokasi Penelitian}

Kecamatan Poleang Tenggara

memiliki luas Wilayah 132,57 $\mathrm{Km}^{2}$ dengan perincian. Berdasarkan posisi geografisnya, Kecamatan Poleang Tenggara memiliki batas - batas yaitu ( Profil Kabupaten/Kota, 2006):

a. Sebelah Utara berbatasan dengan

Kecamatan Kecamatan Rumbia; b. Sebelah Barat berbatasan dengan Kecamatan Poleang Poleang Timur;

c. Sebelah Selatan berbatasan dengan Laut Banda;

d. Sebelah Timur berbatasan dengan Desa Lora;

\section{Metode}

Jenis penelitian ini adalah penelitian deskriptif menggunakan analisis data kualitatif dan kuantitatif. Metode kualitatif digunakan untuk mengetahui penggunaan tumbuhan sebagai obat untuk hipertensi, bersifat survei eksploratif dengan teknik pengumpulan data menggunakan proses wawancara dan pengamatan langsung atau observasi dilapangan, serta studi literatur. Data diperoleh dengan mengumpulkan sampel tanaman yang digunakan sebagai ramuan, difoto kemudian dilakukan studi literatur atau penelusuran pustaka untuk menentukan kebenaran identitas tanaman serta nama ilmiahnya. Pengetahuan empirik yang diperoleh dilakukan studi komparasi terhadap studi atau data ilmiah dari referensi yang ditemukan.

\section{Analisis Kuantitatif}

Analisis kuantitatif dilakukan dengan menghitung frekuensi sitasi. Perhitungan frekuensi sitasi bertujuan untuk mengetahui frekuensi penggunaan tumbuhan obat yang digunakan untuk 
mengobati hipertensi. Frekuensi sitasi dihitung dengan menggunakan rumus:

Frekuensi sitasi $(\%)=(\mathrm{N} / \mathrm{T}) \times 100$

(Kumar et al., 2014).

Keterangan: $\mathrm{N}$ = Jumlah responden yang menyebutkan nama tumbuhan berpotensi obat. $\mathrm{T}=$ Jumlah keseluruhan reponden

\section{Penentuan Informan}

Data informasi jenis, bagian tumbuhan yang digunakan dan cara pengolahan tumbuhan diperoleh dengan wawancara. Penentuan Informan menggunakan metode snowball sampling yaitu teknik pemilihan kunci responden yang dilakukan berdasarkan rekomendasi dari responden sebelumya (Bernard, 2002). Informan ditentukan berdasarkan keterangan dari tokoh masyarakat adat, kepala suku, kepala desa dan sumber terpercaya lainnya yang mengetahui halhal yang berkaitan erat dengan penelitian yang dilakukan.

\section{HASIL DAN PEMBAHASAN}

Penelitian ini menggunakan 10 informan yang terdiri dari Pengobat tradisional (Battra) dan informan lainnya dari 5 (lima) desa di Kecamatan Poleang Tenggara Kabupaten Bombana Provinsi Sulawesi Tenggara. Nama ilmiah tanaman tidak diketahui oleh informan sehingga untuk mengetahui nama ilmiah diperoleh melalui penelusuran pustaka atau studi referensi maupun melalui laman plantamor.com (2019). Dari hasil wawancara dan observasi diperolah data data sebagai berikut :

a. Daftar Tanaman Obat Hipertensi di Kecamatan Poleang Tenggara Kabupaten Bombana

Tabel 1. Daftar tanaman obat berdasarkan bagian tanaman yang digunakan dan cara pengolahan

\begin{tabular}{|c|c|c|c|c|c|}
\hline $\begin{array}{l}\text { Nama } \\
\text { Tanaman } \\
\text { Obat }\end{array}$ & $\begin{array}{l}\text { Nama } \\
\text { Daerah }\end{array}$ & Nama Latin & $\begin{array}{l}\text { Bagian } \\
\text { Yang } \\
\text { Digunak } \\
\text { an }\end{array}$ & $\begin{array}{l}\text { Cara } \\
\text { Pengolahan }\end{array}$ & $\begin{array}{l}\text { Frekuensi } \\
\text { Sitasi (10\%) }\end{array}$ \\
\hline Kersen & Gersen & $\begin{array}{l}\text { Muntingia } \\
\text { calabura L. }\end{array}$ & Daun & $\begin{array}{lr}\text { Beberapa } & \text { lembar } \\
\text { daun } & \text { gersen } \\
\text { direbus } & \text { lalu } \\
\text { disaring. } & \end{array}$ & 30 \\
\hline Salam & Salam & $\begin{array}{l}\text { Syzygium } \\
\text { polyanthum }\end{array}$ & Daun & $\begin{array}{lr}\text { Beberapa } & \text { lembar } \\
\text { daun } & \text { salam } \\
\text { direbus } & \text { lalu } \\
\text { disaring. } & \end{array}$ & 30 \\
\hline Sirsak & Srikaja & $\begin{array}{l}\text { Annona } \\
\text { muricata }\end{array}$ & Daun & $\begin{array}{ll}\text { Beberapa } & \text { lembar } \\
\text { daun } & \text { srikaya }\end{array}$ & 30 \\
\hline
\end{tabular}




\begin{tabular}{|c|c|c|c|c|c|}
\hline $\begin{array}{l}\text { Nama } \\
\text { Tanaman } \\
\text { Obat }\end{array}$ & $\begin{array}{l}\text { Nama } \\
\text { Daerah }\end{array}$ & Nama Latin & $\begin{array}{l}\text { Bagian } \\
\text { Yang } \\
\text { Digunak } \\
\text { an }\end{array}$ & $\begin{array}{l}\text { Cara } \\
\text { Pengolahan }\end{array}$ & $\begin{array}{l}\text { Frekuensi } \\
\text { Sitasi (10\%) }\end{array}$ \\
\hline & & & & $\begin{array}{ll}\text { direbus } & \text { lalu } \\
\text { disaring. } & \end{array}$ & \\
\hline Keji beling & $\begin{array}{l}\text { Pecah } \\
\text { beling }\end{array}$ & $\begin{array}{l}\text { Strobilanthes } \\
\text { crispa }\end{array}$ & Daun & $\begin{array}{l}\text { Beberapa lembar } \\
\text { daun pecah beling } \\
\text { direbus lalu } \\
\text { disaring. }\end{array}$ & 10 \\
\hline $\begin{array}{l}\text { Belimbing } \\
\text { wuluh }\end{array}$ & Bainang & $\begin{array}{l}\text { Averrhoa } \\
\text { bilimbi }\end{array}$ & Daun & $\begin{array}{lr}\text { Beberapa lembar } \\
\text { daun belimbing } \\
\text { direbus lalu } \\
\text { disaring. }\end{array}$ & 10 \\
\hline $\begin{array}{l}\text { Bawang } \\
\text { putih }\end{array}$ & $\begin{array}{l}\text { Lasuna } \\
\text { pute }\end{array}$ & $\begin{array}{l}\text { Allium } \\
\text { sativum }\end{array}$ & Umbi & $\begin{array}{l}\text { Iris tipis-tipis } \\
\text { bawang putih lalu } \\
\text { siram dengan air } \\
\text { panas (diseduh). } \\
\text { Kemudian di } \\
\text { saring. }\end{array}$ & 10 \\
\hline Mengkudu & Baja & $\begin{array}{l}\text { Morinda } \\
\text { citrifolia L. }\end{array}$ & Buah & $\begin{array}{l}\text { Buah mengkudu } \\
\text { yang sudah masak } \\
\text { ditumbuk, } \\
\text { diperas lalu } \\
\text { disaring }\end{array}$ & 30 \\
\hline Seledri & Soo & $\begin{array}{l}\text { Apium } \\
\text { graveolens L. }\end{array}$ & $\begin{array}{l}\text { Semua } \\
\text { bagian } \\
\text { tanaman } \\
\text { (herba) }\end{array}$ & $\begin{array}{l}\text { Semua bagian } \\
\text { tanaman direbus } \\
\text { lalu disaring }\end{array}$ & 10 \\
\hline $\begin{array}{l}\text { Sambung } \\
\text { nyawa }\end{array}$ & $\begin{array}{l}\text { Sambun } \\
\text { g nyawa }\end{array}$ & $\begin{array}{l}\text { Gynura } \\
\text { procumbens }\end{array}$ & Daun & $\begin{array}{l}\text { Beberapa daun } \\
\text { sambung nyawa } \\
\text { dibersihkan lalu } \\
\text { dikunyah sampai } \\
\text { halus. }\end{array}$ & 10 \\
\hline Sukun & Baka & $\begin{array}{l}\text { Artocarpus } \\
\text { communis }\end{array}$ & Daun & $\begin{array}{l}\text { Beberapa daun } \\
\text { sukun yang sudah } \\
\text { kering direbus } \\
\text { lalu disaring. }\end{array}$ & 20 \\
\hline Mahoni & Mahoni & $\begin{array}{l}\text { Swietenia } \\
\text { mahagoni L. } \\
\text { Jacq. }\end{array}$ & Biji & $\begin{array}{l}\text { Beberapa biji } \\
\text { mahoni diseduh } \\
\text { dengan air panas } \\
\text { lalu saring. }\end{array}$ & 10 \\
\hline
\end{tabular}




\begin{tabular}{|c|c|c|c|c|c|}
\hline $\begin{array}{l}\text { Nama } \\
\text { Tanaman } \\
\text { Obat }\end{array}$ & $\begin{array}{l}\text { Nama } \\
\text { Daerah }\end{array}$ & Nama Latin & $\begin{array}{l}\text { Bagian } \\
\text { Yang } \\
\text { Digunak } \\
\text { an }\end{array}$ & $\begin{array}{l}\text { Cara } \\
\text { Pengolahan }\end{array}$ & $\begin{array}{l}\text { Frekuensi } \\
\text { Sitasi }(10 \%)\end{array}$ \\
\hline Alpukat & Alpoka & $\begin{array}{l}\text { Persea } \\
\text { americana }\end{array}$ & Daun & $\begin{array}{l}\text { Beberapa daun } \\
\text { alpukat direbus } \\
\text { lalu disaring. }\end{array}$ & 10 \\
\hline $\begin{array}{l}\text { Kumis } \\
\text { kucing }\end{array}$ & $\begin{array}{l}\text { Kumis } \\
\text { kucing }\end{array}$ & $\begin{array}{l}\text { Orthosiphon } \\
\text { aristatus }\end{array}$ & Daun & $\begin{array}{lr}\text { Beberapa } & \text { daun } \\
\text { kumis } & \text { kucing } \\
\text { direbus } & \text { lalu } \\
\text { disaring. } & \end{array}$ & 10 \\
\hline Serai & Serre & $\begin{array}{l}\text { Cymbopogon } \\
\text { citrates }\end{array}$ & Batang & $\begin{array}{lr}\text { Serai } & \text { yang } \\
\text { digunakan } & \text { diris } \\
\text { tipis-tipis } & \text { lalu } \\
\text { direbus, } & \\
\text { kemudian } & \\
\text { disaring. } & \end{array}$ & 10 \\
\hline Pepaya & Kaliki & $\begin{array}{l}\text { Carica } \\
\text { papaya }\end{array}$ & Daun & $\begin{array}{l}\text { Beberapa daun } \\
\text { pepaya direbus } \\
\text { lalu disaring. }\end{array}$ & 10 \\
\hline Nangka & Panasa & $\begin{array}{l}\text { Artocarpus } \\
\text { heterophyllu } \\
s\end{array}$ & Daun & $\begin{array}{l}\text { Beberapa daun } \\
\text { nangka direbus } \\
\text { lalu disaring }\end{array}$ & 20 \\
\hline Jarak & $\begin{array}{l}\text { Cangi- } \\
\text { cangi }\end{array}$ & $\begin{array}{l}\text { Ricinus } \\
\text { communis }\end{array}$ & Daun & $\begin{array}{l}\text { Beberapa daun } \\
\text { jarak direbus lalu } \\
\text { disaring. }\end{array}$ & 20 \\
\hline Sambiloto & $\begin{array}{l}\text { Sambilot } \\
\mathrm{o}\end{array}$ & $\begin{array}{l}\text { Andrographi } \\
\text { s paniculata }\end{array}$ & Daun & $\begin{array}{l}\text { Beberapa daun } \\
\text { sambiloto direbus } \\
\text { lalu disaring }\end{array}$ & 20 \\
\hline Daun Afrika & Klorofil & $\begin{array}{l}\text { Vernonia } \\
\text { amygdalina }\end{array}$ & Daun & $\begin{array}{l}\text { Beberapa daun } \\
\text { klorofil direbus } \\
\text { lalu disaring. }\end{array}$ & 10 \\
\hline Kelapa & Kaluku & $\begin{array}{l}\text { Cocos } \\
\text { nucifera }\end{array}$ & Daun & $\begin{array}{l}\text { Daun kelapa yang } \\
\text { kering dipotong } \\
\text { kecil-kecil lalu } \\
\text { direbus, } \\
\text { kemudian } \\
\text { disaring. }\end{array}$ & 30 \\
\hline
\end{tabular}

b. Bagian tanaman yang perbedaan dalam pemanfaatan bagian dimanfaatkan tanaman obat. Bagian-bagian tanaman yang digunakan adalah daun, biji, buah

Dari wawancara dengan informan juga didapatkan bahwa terdapat dan rimpang 
Tabel 2. Daftar tanaman obat berdasarkan bagian tanaman yang digunakan, cara pengolahan untuk penyakit Hipertensi.

\begin{tabular}{|c|c|c|}
\hline Bagian & Jumlah & Persen \\
\hline tanaman yang & & \\
\hline Daun & 15 & 75 \\
\hline Umbi & 1 & 5 \\
\hline Biji & 1 & 5 \\
\hline Buah & 1 & 5 \\
\hline Batang & 1 & 5 \\
\hline Herba & 1 & 5 \\
\hline
\end{tabular}

c. Cara pengolahan tanaman

Adapun cara pengolahan tanaman obat oleh masyarakat di Kecamatan Poleang Tenggara Kabupaten Bombana yaitu dengan cara direbus, diseduh, diblender dan ada juga yang lansung dikunyah. d. Penyebaran famili tanaman etnomedisin

Adapun famili tanaman berkhasiat obat di Kecamatan Poleang Tenggara Kabupaten Bombana dapat dilihat pada gambar 4 .

Tabel 3. Cara Pengolahan Tanaman

\begin{tabular}{ccc}
\hline Cara pengolahan tanaman & Jumlah & Persen (\%) \\
\hline Direbus & 16 & 80 \\
\hline Diseduh & 2 & 10 \\
\hline Ditumbuk /diblender & 1 & 5 \\
\hline Dikunyah & 1 & 5
\end{tabular}




\section{Cara pengolahan tanaman}

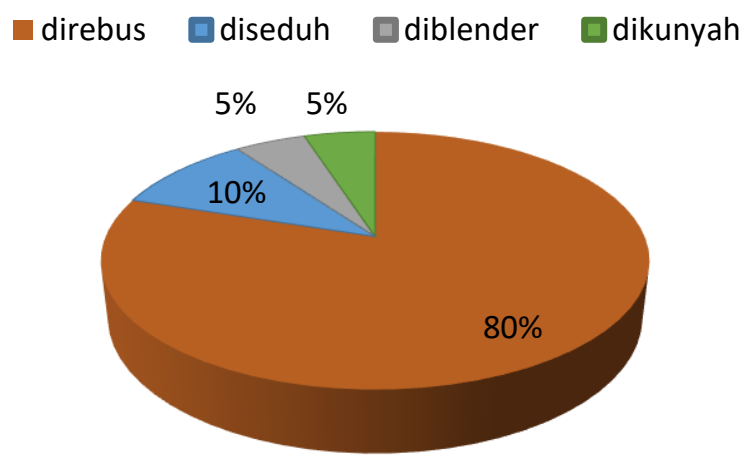

Gambar 2. Cara pengolahan tanaman

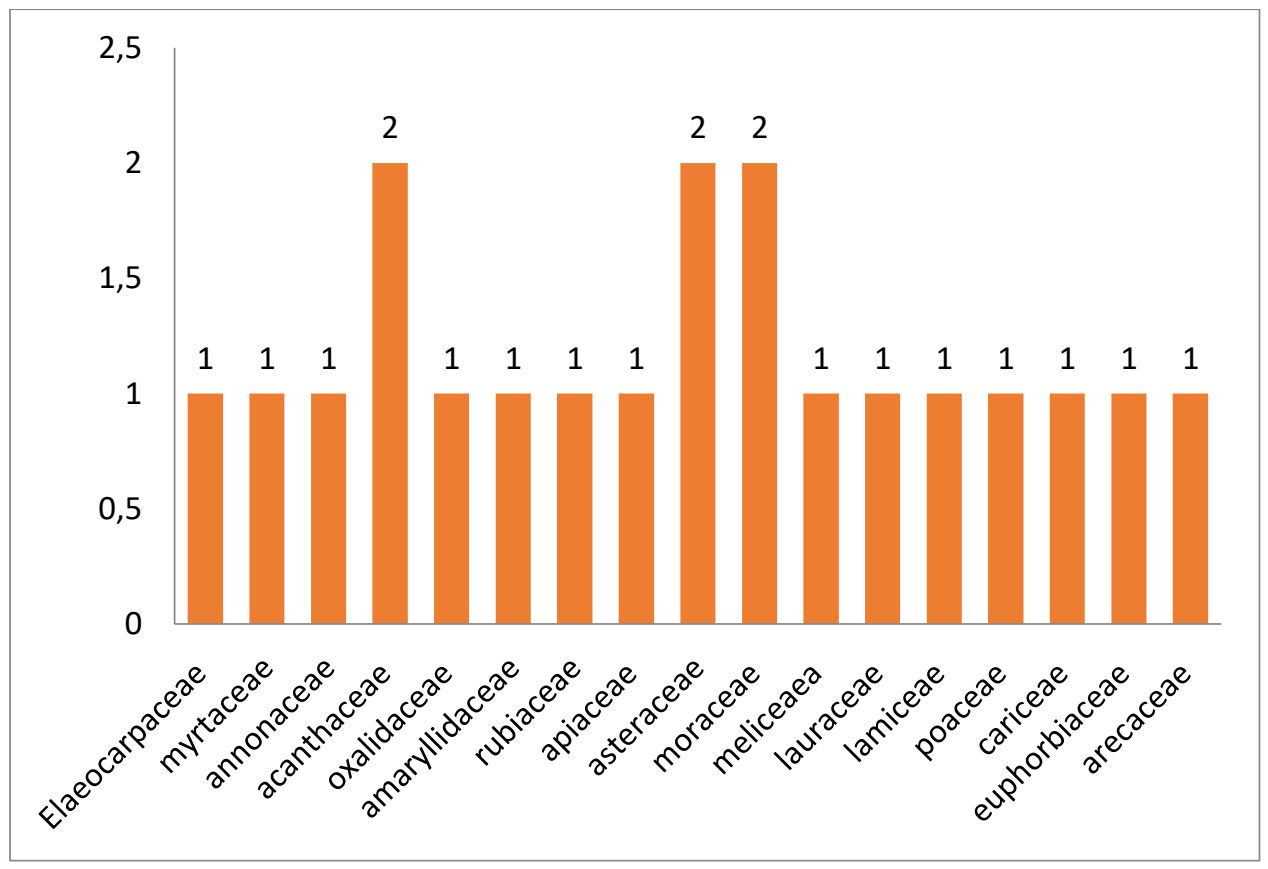

Gambar 3. Penyebaran famili tanaman etnomedisin

Para peneliti saat ini masih meyakini bahwa keberadaan produk bahan alam cukup penting dalam penemuan senyawa baru yang dapat digunakan dalam pengembangan obat baru untuk berbagai penyakit termasuk hipertensi. Kenyataannya, 877 senyawa baru telah dikembangkan selama periode 1981-2002 yang meliputi 6\% produk bahan alam, 27\% turunan produk bahan alam, dan 16\% berupa senyawa sintetik yang dikembangkan berdasarkan produk bahan alam (Newman et al., 2003). Perhatian dunia terhadap obat-obat bahan alam menunjukkan peningkatan, hal ini terbukti dari penggunaan obat bahan alam 
di

negara maju mencapai $65 \%$ dan pembelanjaan obat bahan alam di pasar global pada tahun 2000 mencapai 43 milyar dolar Amerika. Sementara itu dari 40.000 spesies tumbuhan

dunia, diperkirakan 30.000 spesies tumbuh di kepulauan Indonesia. Selain itu di

Indonesia

diperkirakan ada 9.600 spesies tanaman yang digunakan untuk pengobatan berbagai macam penyakit (Dafriani, 2016)

Pewarisan pengetahuan tradisional telah dimanfaatkan oleh 400 ragam etnis untuk pemeliharaan kesehatan maupun tumbuhan obat sebagian besar dilakukan secara lisan, sehingga baru 300 spesies tanaman yang digunakan sebagai bahan obat oleh industri obat tradisional, 38 produk tanaman obat yang terdaftar sebagai obat herbal terstandar dan 6 produk sebagai fitofarmaka.

Berdasarkan hasil wawancara dengan 10 informan pada masyarakat di Kecamatan Poleang Tenggara ditemukan sebanyak 20 jenis tanaman obat yang digunakan untuk mengobati hipertensi. Tanaman tersebut antara lain gersen, salam, sirsak, pecah beling, bainang (belimbing wuluh), lasuna pute (bawang putih), baja (mengkudu), soo (seledri), sambung nyawa, baka (sukun), mahoni, alpoka (alpukat), kumis kucing, serai, kaliki (papaya), panasa (nangka), cangi- cangi (jarak), sambiloto, klorofil, dan daun kaluku (kelapa). Di daerah lain seperti yang telah dilaporkan oleh (Qurthoniah, 2018) bahwa alpukat dan kumis kucing juga digunakan oleh masyarakat di kecamatan Solokan Jeruk Kabupaten Bandung untuk mengobati penyakit darah tinggi atau hipertensi.

Sementara itu hasil studi dari Melamba (2019) menyebutkan untuk penyakit darah tinggi pada Orang Moronene di Bombana diobati dengan e'eni atau air kelapa. Dianjurkan jenis buah kelapa yang berwarna merah, dengan cara kelapa dipanjat kemudian buah kelapa digendong agar kelapa tidak langsung dijatuhkan ke tanah. Setelah kelapa dikupas atau dibelah maka air kelapa tersebut dibacakan salawat Nabi. Sedangkan masyarakat Bombana yang menempati kecamatan Poleang Tenggara memanfaatkan bagian daun kelapa kering yang dipotong kecil-kecil lalu direbus, kemudian disaring lalu air rebusannya diminum. Kedua temuan ini sama sama menggunakan bagian dari pohon kelapa meskipun dengan cara pengunaan yang berbeda sebagai implikasi beragamnya kearifan lokal disetiap tempat.

Untuk mengetahui seberapa sering tanaman obat tersebut disebut oleh informan digunakan rumus sitasi. Tujuannya untuk mendapatkan tanaman obat yang paling sering direkomendasikan oleh battra ataukah informan dalam 
mengobati hipertensi. Hasil yang didapatkan yakni tanaman daun kersen, daun salam, daun sirsak, buah mengkudu dan daun kelapa memiliki nilai frekuensi sitasi sebesar $30 \%$ atau sebanyak 3 (tiga) orang dari 10 orang informan menyebutkan tanaman obat ini digunakan untuk mengobati hipertensi . Hal ini dapat dimaknai bahwa tanaman obat tersebut memiliki tingkat efektifitas dalam mengobati penyakit hipertensi bagi masyarakat di kecamatan Poleang Tenggara kabupaten Bombana.

Bagian tanaman yang paling banyak dimanfaatkan adalah daun sebesar $75 \%$, kemudian bagian biji $5 \%$, buah $5 \%$, batang $5 \%$, herba $5 \%$. Daun merupakan organ tumbuhan yang paling mudah diperoleh, sehingga merupakan bagian yang paling sering dicoba

oleh manusia khususnya pada daerah tropis (Silalahi et al, 2018). Penggunaan bagian daun yang lebih banyak digunakan sebagai obat tradisional merupakan hal yang umum karena kemudahannya untuk diolah, dan banyaknya kandungan metabolit sekunder di dalam daun (Chekole, 2017) hal inilah yang mungkin mempengaruhi khasiat yang diperoleh lebih banyak pada bagian daun. Anatomi daun tersusun atas sel-sel parenkim yang memiliki metabolisme aktif dalam memproduksi fotosintat yang diduga mengandung unsur-unsur zat organik yang memiliki sifat menyembuhkan penyaki, juga berbagai asimilat yang mempengaruhi terbentuknya metabolit. Penggunaan bagian tumbuhan tertentu memiliki beberapa korelasi terkait dengan aspek praktis, ekologis, dan fitokimia (Abdul Kodir et al., 2017). Keuntungan lain dari daun adalah memiliki serat yang lunak, dan banyak mengandung senyawa kimia yang dapat digunakan sebagai obat (Handayani, 2003). Hal ini sesuai dengan penelitian lain bahwa bagian yang paling banyak digunakan atau dimanfaatkan masyarakat adalah bagian daun, dan paling banyak sedikit digunakan bagian bunga, buah, dan rimpang (Maryadi, 2012).

Penggunaan bagian daun terdapat pada 15 tanaman dari 20 jenis tanaman obat yang digunakan oleh masyarakat di Kecamatan Poleang Tenggara Penggunaan secara empiris ini dapat di rasionalisasi secara ilmiah, menggunakan metode pendekatan pustaka berdasarkan data data ilmiah yang telah dilaporkan. Muntingia calabura (Muntingiaceae) merupakan Jamaican cherry yang dikenal di Indonesia sebagai Kersen. Metabolit sekunder sebagai konstituen kimia telah diisolasi dari daun, batang dan akar $M$. calabura dengan pelarut yang berbeda. Flavonoid merupakan konstituen utama penyusun metabolit sekunder dari tanaman ini (Putri \& Fatmawati, 2019). Isolasi dari ekstrak metanol daun dari $M$. 
calabura yang dipartisi dengan etil asetat, petroleum eter, kloroform dan butanol dihasilkan sekitar 60 senyawa yang terdiri dari flavanon, kalkon, flavon dan flavan (Putri \& Fatmawati, 2019).

Flavonoid telah dikonsumsi oleh manusia sejak lama. Flavonoid memiliki kemampuan biologi yang luas dalam menjaga kesehatan manusia dan membantu mengurangi resiko berbagai penyakit, khususnya untuk efek anti hipertensi. Senyawa ini menghasilkan kemampuan untuk mengurangi stres oksidatif, menghambat aktifitas angiotensin converting enzim, meningkatkan relaksasi endotel pembuluh darah, mengatur signaling sel dan ekspresi gen. Kemampuan untuk menggunakan flavonoid sebagai angiotensin-converting enzyme (ACE) inhibitor dalam mengatur tekanan darah telah diteliti sejak beberapa dekade yang lalu dan hampir semua telah terbukti efektif dalam menekan kerja ACE (Widiasari, 2018). Efek flavonoid juga berkaitan dengan perannya sebagai antioksidan potensial pencegah terbentuknya radikal bebas, perlengketan sel darah merah, dan kerusakan HDL-C. Mempunyai efek menurunkan tekanan darah dan mengontrol profil lipid dengan cara menghambat enzim ACE (Carolia \& Ghaisani, 2016).

Penggunaan daun salam sebagai obat hipertensi telah dilaporkan dalam berbagai studi. (Dafriani, 2016) meneliti pengaruh rebusan daun salam tekanan darah pasien hipertensi di sungai bungkal, bahwa dari 10 responden kelompok intervensi yang mengkonsumsi air rebusan daun salam 2 kali sehari sebanyak setengah gelas $(120 \mathrm{ml})$ pada hari-I sebanyak $10 \%$ dari responden mengalami penurunan tekanan darah, pada hari ke-2 sebanyak 50\%, pada hari ke-3 hingga hari ke-5 sebanyak $100 \%$ mengalami penurunan tekanan darah. Pengaruh ini ditunjukkan rerata perubahan tekanan darah Sistolik pre-test dan post test penderita Hipertensi adalah $40 \mathrm{mmHg}$ dengan standar deviasi $9.428 \mathrm{mmHg}$. Hasil uji statistik $t$-test didapatkan $p$ value $0.000<a$ (0.05) yang berarti ada pengaruh antara tekanan darah sistolik penderita Hipertensi sebelum dan sesudah pemberian air rebusan daun salam. Pengaruh rebusan daun salam terhadap penurunan tekanan darah pada lansia juga telah dilaporkan oleh (Asih, 2018). Dalam studi tersebut disimpulkan bahwa air rebusan daun salam berpengaruh terhadap penurunan tekanan darah sistolik dan tidak berpengaruh terhadap penurunan tekanan darah lansia dengan hipertensi. Sehingga daun salam dapat digunakan sebagai salah satu terapi herbal untuk menurunkan tekanan darah pada lansia dengan hipertensi. 
Penelitian yang mengkaji pengaruh ekstrak daun sukun (Artocarpus altilis) terhadap aktivitas ACE telah dilaporkan oleh (Siddesha et al., 2011). Ekstrak yang diuji berupa ekstrak etanol panas, ekstrak etil asetat dingin dan ekstrak air panas. Ekstrak etanol panas menunjukkan aktivitas penghambatan ACE yang kuat dengan nilai $\mathrm{IC}_{50} \quad 54,08 \pm 0,29 \mu \mathrm{g} \mathrm{mL}^{-1}$ diikuti oleh ekstrak etil asetat dingin $\left(\mathrm{IC}_{50}\right.$ $85,44 \pm 0,85 \mu \mathrm{g} \mathrm{mL}^{-1}$ ). Sebaliknya, ekstrak air panas menunjukkan penghambatan minimum dengan nilai $\mathrm{IC}_{50}$ $765,52 \pm 11,97 \mu \mathrm{g} \mathrm{mL}^{-1}$ pada konsentrasi maksimum yang diuji. Selanjutnya, analisis fitokimia menunjukkan distribusi tanin, fenolat, glikosida, saponin, steroid, terpenoid dan antrakuinon yang bervariasi dalam ekstrak daun dingin dan panas. Korelasi antara analisis fitokimia dan aktivitas penghambatan ACE menunjukkan bahwa kandungan senyawa glikosidik dan fenolik yang tinggi terlibat dalam aktivitas penghambatan ACE. Kesimpulannya, penelitian ini mendukung pemanfaatan daun A. Altilis dalam pengobatan tradisional untuk pengobatan hipertensi yang lebih baik (Siddesha et al., 2011)

Khasiat untuk mengatasi hipertensi juga ditunjukkan oleh daun kumis kucing (Orthosiphon stamineus). Daun Kumis kucing biasa digunakan sebagai teh herbal untuk hipertensi, diuresis, untuk mengobati rematik, diabetes, lithiasis urinaria, oedema, demam erupsi, influenza, hepatitis, penyakit kuning, dan lithiasis bilier (Shokoohinia et al., 2018). Khasiat tersebut terkait dengan senyawa kimia yang dilaporkan (Shokoohinia et al., 2018) yaitu enam senyawa flavonoid yang diisolasi dari daun kumis kucing. Berdasarkan analisis kimia dan spektral strukturnya dijelaskan sebagai eupatorin, sinensetin, $\quad 5$-hidroksi-6,7,3', $4^{\prime}$ tetramethoxyflavone, salvigenin, 6hydroxy-5,7,4'-trimethoxyflavone dan 5,6,7,3'-tetramethoxy-4'-hydroxy-8-Cprenylflavon. Sementara itu, penelitian Sangging dan Sari (2017) mengenai terapi non-farmakologi dengan pemberian teh daun sirsak (Annona muricata Linn) ditemukan mampu mempengaruhi tekanan darah. Khasiat tersebut karena kandungan kimia daun sirsak yaitu senyawa monotetrahidrofuran asetogenin, seperti anomurisin A dan B, gigantetrosin A, annonasin-10-one, murikatosin A dan B, annonasin, dan goniotalamisin (Sangging dan Sari, 2017).

Riset Tumbuhan Obat dan Jamu (Ristoja) yang dilakukan pada tahun 2012, 2015, dan 2017 telah mengumpulkan ribuan ramuan dan diantaranya mengandung seledri (Apium graveolens L). Analisis lanjut ini mempelajari lebih mendalam pemanfaatan empiris seledri sebagai bahan obat tradisional oleh penyehat tradisional (Hattra) melalui wawancara dan observasi. Berdasarkan 
data Ristoja tersebut ditemukan 90 ramuan dan diantaranya terdapat 20 nama lokal ramuan yang yang dimanfaatkan oleh Hattra. Pemanfaatan empiris seledri oleh Hattra teridentifikasi untuk pengobatan 10 jenis penyakit, terbanyak digunakan untuk pengobatan hipertensi dan telah diketahui justifikasi ilmiah melalui literatur (Handayani dan Widowati, 2020). Ramuan tradisional yang dapat digunakan dalam penatalaksanaan hipertensi selain seledri adalah belimbing wuluh (Averrhoa bilimbi). Berdasarkan penelitian (Mulyani et al., 2015) didapatkan ekstrak daun belimbing wuluh dosis 105,034 mg/100 gram BB memiliki efektivitas yang sama dengan kelompok Kaptopril 2,5 mg/kg BB dalam menurunkan tekanan darah tikus putih jantan hipertensi. Sementara itu dari hasil penelitian Anggreni et al (2018) menunjukkan adanya perbedaan tekanan darah ibu hamil antara kelompok kontrol dan kelompok eksperimen setelah minum air rebusan daun belimbing wuluh selama 1 bulan, dimana tekanan darah kelompok eksperimen lebih rendah menjadi ratarata 123,7 mmHg sedangkan kelompok kontrol masih sebesar rata-rata 132,6 $\mathrm{mmHg}$.

Beberapa studi juga menunjukkan potensi bawang putih sebagai antihipertensi. Pada penelitian in vitro ditemukan bahwa dipeptida pada ekstrak bawang putih (A.sativum) setelah dihidrolisis dengan enzim papain memiliki aktivitas inhibisi terhadap ACE, penelitian lainnya pemberian A.sativum diketahui mampu memperbaiki fungsi ginjal terhadap tikus yang dinduksi hipertensi 2 Kidney One Clip (2K1C) (Raharjo et al., 2020). Terapi komplementer untuk hipertensi menggunakan daun mengkudu juga dapat dikuatkan berdasarkan penelitian dari (Wiliyanarti \& Silaturrrohmih, 2020) yang menunjukkan adanya efek ekstrak mengkudu terhadap penurunan tekanan darah pada tikus Wistar hipertensi. Sementara biji mahoni yang digunakan oleh masyarakat di kecamatan Poleang Tenggara juga ditemukan memiliki pengaruh terhadap tekanan darah. Berdasarkan studi (Kasumayanti \& Putri, 2018) bahwa konsumsi ekstrak biji mahoni memiliki pengaruh terhadap penurunan tekanan darah pada penderita hipertensi . Demikian pula daun sambung nyawa memiliki aktivitas antihipertensi dengan cara menginhibisi aktivitas angiotensin converting enzyme (ACE). Selain itu, daun sambung nyawa dapat berpotensi sebagai terapi adjuvan hipertensi karena dapat memblok influks ion kalsium melewati VDCC (Voltage Dependent Calsium Channel) dan ROCC (Receptor-Operated Calsium Chennel), kedua efek ini diteliti secara in vivo (Hoe et al., 2007). 
Strobilanthes crispus atau secara lokal dikenal dengan "pecah beling” atau "keji beling” tidak hanya digunakan oleh masyarakat di Poleang Tenggara. Berdasarkan temuan (Cheong et al., 2016) daun pecah beling telah digunakan secara tradisional di Malaysia untuk tekanan darah tinggi. Studi dari (Cheong et al., 2016) juga memeriksa konstituen fitokimia daun pecah beling dan melaporkan bahwa daun ini tmengandung senyawa ester glikosidik komponen dari asam caffeic, asam p-voumaric, asam vanilat, asam ferulat, asam syringic, sitosterol, campesterol, asam heksadekanoat, metilester, lupeol, fitol, stigmasterol, senyawa flavonoid seperti (+)-catechin, (-)-epicatechin, rutin, dan lain-lain. Penggunaan daun sambiloto (Andrographis paniculata) sebagai antihipertensi baik secara empiris maupun studi ilmiah telah banyak dilaporkan. Beberapa senyawa diterpenoid tipe labdan yang memiliki efek antihipertensi telah diidentifikasi dalam ekstrak $A$. paniculata dengan mekanisme meningkatkan pelepasan NO, adanya efek penghambatan pada ACE dan spesies oksigen reaktif (ROS) (Chrysant \& Chrysant, 2017).

Tumbuhan yang dimanfaatkan oleh masyarakat di kecamatan Poleang Tenggara juga berasal dari rempah yang digunakan sebagai bumbu dapur yaitu serai maupun sebagai sayuran yakni daun pepaya. Serai telah digunakan secara luas dalam pengobatan tradisional di beberapa negara termasuk Brasil, Cina, dan Asia Selatan untuk pengobatan hipertensi karena efek vasodilatasi dari bahan aktifnya yaitu sitral. Selain itu, efek penurunan tekanan darah dari serai telah dikaitkan dengan sifat vasorelaksan dan antioksidannya (Chrysant \& Chrysant, 2017). Daun pepaya telah digunakan oleh masyarakat Indonesia sebagai sayuran sehat, obat untuk mengatasi berbagai penyakit termasuk tekanan darah tinggi. (Hasimun et al., 2020) meneliti pengaruh diet sediaan Nori dari daun pepaya terhadap hipertensi dan kekakuan arteri. Dari studi tersebut disimpulkan bahwa suplementasi daun pepaya dalam sediaan nori berpengaruh dalam menstabilkan darah sistolik dan diastolik tekanan dan mengurangi kekakuan arteri pada model hewan hipertensi. Daun pepaya memiliki kandungan serat makanan yang tinggi dan senyawa polifenol, seperti flavonoid, saponin, pro-antosianin, tokoferol dan benzil isotiosianat. Kandungan nutrisi yang ada didalamnya juga telah memberikan efek menguntungkan pada peningkatan yang signifikan dalam perlindungan sistem kardiovaskular (Santana et al., 2019).

Penggunaan tanaman obat untuk mengatasi tekanan darah tinggi pada masyarakat di kecamatan Poleang Tenggara tidak hanya berkisar pada 
sayuran, bumbu dapur maupun tumbuhan obat, tetapi juga terhadap bagian daun dari tumbuhan yang menghasilkan buahbuahan seperti daun Alpukat dan daun Nangka. Namun demikian khasiat yang diperoleh tersebut juga sejalan dengan beberapa studi ilmiah. Menurut (Odubanjo et al., 2016) daun Alpukat memiliki kandungan fenol total $(92,9$ $\mathrm{mg} / \mathrm{g}$ ) dan flavonoid (51,o $\mathrm{mg} / \mathrm{g}$ ) yang lebih tinggi secara nyata $(\mathrm{P}<0,05)$ dibandingkan bijinya [fenol total $(57,1$ $\mathrm{mg} / \mathrm{g})$ dan flavonoid total $(19,48 \mathrm{mg} / \mathrm{g})$ g)]. Selanjutnya, sifat antioksidan daun juga secara signifikan $(\mathrm{P}<0,05)$ lebih tinggi daripada biji alpukat. Meski demikian, biji memiliki efek penghambatan yang lebih tinggi terhadap ACE dibandingkan ekstrak daun Alpukat. Kandungan antioksidan dan efek penghambatan ACE pada daun dan biji buah alpukat ini dapat menjadi bagian dari mekanisme penggunaannya secara empirik pada pengelolaan/pengobatan hipertensi. Daun Nangka memiliki kandungan fitokimia seperti karotenoid, flavonoid, asam volatil sterol, dan tanin (Ranasinghe et al., 2019). Kandungan Alkaloid dan flavonoid pada daun nangka lebih tinggi dibandingkan pada bijinya (Amadi et al., 2018). Nangka mengandung senyawa fungsional yang memiliki kemampuan untuk mengurangi berbagai penyakit seperti tekanan darah tinggi, penyakit jantung, stroke, dan pengeroposan tulang. Nangka juga kaya potasium yang membantu menurunkan tekanan darah dan membalikkan efek natrium yang menyebabkan kenaikan tekanan darah sehingga mempengaruhi jantung dan pembuluh darah (Ranasinghe et al., 2019).

Pencegahan dan pengelolaan hipertensi adalah tantangan kesehatan masyarakat utama di seluruh dunia. Tekanan darah tinggi yang tidak terkontrol dapat menyebabkan harapan hidup yang lebih pendek dan morbiditas yang lebih tinggi karena risiko tinggi komplikasi kardiovaskular seperti penyakit jantung koroner (yang menyebabkan serangan jantung) dan stroke, gagal jantung kongestif, ketidakteraturan irama jantung, dan gagal ginjal (Huang et al., 2013). Studi ilmiah terhadap daun jarak (Richinus communis) mengandung protein, karbohidrat, fenol/tanin, flavonoid, glikosida dan steroid (Yadav \& Agarwala, 2011). Dimana konstituen bioaktif utama ini termasuk peptida dapat penghambat angiotensin Iconverting enzyme (ACE). Flavonoid, asam fenolik, polifenol, tanin, polisakarida, saponin, dapat mengurangi tekanan darah dengan mekanisme yang berbeda, seperti efek penghambatan ACE, antioksidan, vasodilatasi, seperti opiat, pemblokiran saluran $\mathrm{Ca}^{2+}$, dan aktivitas penghambatan chymase (Huang et al., 2013). Vernonia amygdalina atau daun afrika menurut studi (Onyema-iloh et al., 
2018) bahwa ekstrak metanol daun afrika dari analisis fitokimia menunjukkan adanya fenol, alkaloid, flavonoid, saponin dan steroid. Penelitian ini juga melaporkan adanya penurunan serum Kreatinin dan Urea pada tikus hipetertensi setelah mendapat pemberian ekstrak etanol daun afrika.

Beberapa penelitian telah dilakukan untuk mengidentifikasi molekul aktif dalam kelapa dan kemungkinan aktivitas farmakologis dan biologisnya. Senyawa yang teridentifikasi dalam lilin epikutikular daun adalah lupeol metileter, skimmiwallin, dan isoskimmiwallin (Lima et al., 2015). Penggunaan bagian daun dalam pengobatan juga ditemukan di Papua Nugini, hanya saja bagian daun dan akar tanaman muda dikunyah sebagai pengobatan diare dan sakit perut (Holdsworth D, 1992 dalam Lima et al., 2015). Berbeda dengan masyarakat di Kecamatan Poleang Tenggara yang menggunakan daun kelapa untuk menurunkan tekanan darah tinggi. Studi ilmiah pada bagian daun kelapa masih sangat terbatas sebagai antihipertensi, namun studi pada bagian buah kelapa telah banyak dipublikasikan. Berbagai ekstrak, fraksi, dan senyawa yang diisolasi dari berbagai bagian buah kelapa menunjukkan aktivitas yang berbeda, termasuk antihipertensi (Lima et al., 2015). Aktivitas antihipertensi dari ekstrak etanol endocarp C. nucifera (EEC) menggunakan model tikus hipertensi yang diinduksi garam deoxycorticosterone acetate (DOCA). Pemberian EEC secara signifikan mengurangi tekanan darah sistolik rata-rata pada tikus hipertensi yang diinduksi garam DOCA (dari 185,3 \pm 4,7 menjadi 145,6 $\pm 6,1 \mathrm{~mm} \mathrm{Hg}$ ). Efek ini dikaitkan dengan aktivasi langsung jalur oksida nitrat/guanilat siklase serta stimulasi reseptor muskarinik dan/atau jalur siklooksigenase. Aktivitas tersebut dapat dijelaskan dengan adanya senyawa fenolik dan flavonoid dalam ekstrak yang digunakan (Bankar et al., 2011).

Data-data studi ilmiah diatas dapat digunakan sebagai bahan komparasi untuk memvalidasi pengetahuan empirik masyarakat di kecamatan Poleang Tenggara kabupaten Bombana. Khasiat yang didapatkan untuk pengobatan hipertensi bukan tidak mungkin berhubungan dengan kandungan senyawa kimia pada 20 tanaman obat yang berhasil dikumpulkan. Meskipun demikian beberapa studi ilmiah yang dilaporkan masih berupa uji preklinik pada hewan coba, dan beberapa berasal dari uji klinik dengan kriteria responden hipertensi yang berbeda. Akan tetapi hasil studi tersebut dapat dijadikan landasan ilmiah untuk mengkaji potensi lebih lanjut dari 20 tanaman obat ini dengan metode yang lebih komprehensif untuk memastikan khasiatnya sebagai antihipertensi 
sehingga berpeluang dikembangkan sebagai obat baru.

Media preparasi atau cara pengolahan yang paling sering dilakukan yaitu direbus sebesar 80\%, diseduh 10\%, ditumbuk 5\%, dan dikunyah 5\%. Masyarakat Kecamatan Poleang Tenggara lebih sering memanfaatkan dan mengolah tanaman obat dengan cara direbus. Pengolahan dengan cara direbus juga merupakan cara yang paling bayak digunakan beberapa daerah lain. Menurut hasil penelitian (Wardenaar \& Sisillia, 2015) pengolahan yang paling banyak digunakan yaitu dengan cara direbus dan ditumbuk, karena penyakit yang di alami sebagian besar merupakan penyakit dalam dengan cara penggunaannya diminum. Pengolahan dengan cara ini sangat mudah dan hemat karena bisa digunakan berulang kali. Menurut Hardadi dalam Wardenaar \& Sisillia, 2015) menyatakan bahwa perebusan berulang-ulang kali dan bahan ramuan tidak berpengaruh walaupun khasiatnya akan sedikit berkurang.

Tanaman tersebut dimanfaatkan oleh masyarakat sebagai obat tradisional yang merupakan Alternatif dan langkah awal dalam penanganan suatu penyakit. Dari hasil wawancara dengan masyarakat di Kecamatan Poleang Tenggara Kabupaten Bombana, tanaman obat ini umumnya merupakan tanaman liar yang terdapat pada hutan sekitar kebun, namun ada juga sebagian tanaman yang sengaja ditanam sendiri dipekarangan rumah. Masyarakat memanfaatkan jenis tumbuhan obat yang bervariasi mulai dari sayuran, bumbu dapur atau rempah, tanaman obat, dar tingkat herba sampai pohon. Tumbuhan Obat memiliki kelebihan dalam pengobatan hipertensi sebab umumnya tumbuhan obat memiliki fungsi selain mengobati penyakit penyerta sebagai akibat tekanan darah tinggi (Iskandar, 2007).

Dalam rangka melastarikan jenisjenis tanaman obat maka langkah yang harus dilakukan dalam upaya konservasi tanaman obat yang masih tumbuhan liar yaitu apabila jenis tanaman obat tersebut sudah dalam kondisi populasi yang terbatas sedangkan penggunaannya oleh masyarakat masih cukup tinggi serta tanpa diikuti usaha budidaya, maka pengelolaan jenis tumbuhan tersebut adalah dengan merekomendasikan bahwa kawasan tempat tumbuh jenis tumbuhan tersebut harus dilindungi. Namun apabila suatu jenis tumbuhan obat tersebut diketahui dalam kondisi populasi yang masih cukup dan penggunaannya oleh masyarakat juga cukup tinggi, maka pilihannya adalah melakukan pengoleksian jenis tumbuhan untuk ditanam.

\section{KESIMPULAN}

Berdasarkan penelitian yang telah dilakukan disimpulkan bahwa : 
1. Penelitian yang dilakukan didapatkan tanaman yang digunakan sebagai obat untuk penyakit hipertensi yaitu ada 20 jenis spesies tanaman.

2. Bagian tanaman yang digunakan atau dimanfaatkan oleh masyarakat yaitu bagian daun $75 \%$, batang $5 \%$, buah $5 \%$, biji $5 \%$, umbi 5\% dan herba 5\%.

3. Pengolahan tanaman yang digunakan yaitu dengan cara direbus 80\%, diseduh 10\%, ditumbuk 5\% dan dikunyah $5 \%$.

\section{DAFTAR PUSTAKA}

Abdul Kodir, R., Iskandar, Y., Raya Bandung Sumedang Km, J., Sumedang, K., \& Barat, J. (2017). Etnofarmasi Dan Ulasan Bioprospektif Tumbuhan Obat Liar Dalam Pengobatan Tradisional Kampung Adat Cikondang, Kecamatan Pangalengan, Kabupaten Bandung, Jawa Barat. In Farmaka (Vol. 15, Issue 1). https://doi.org/10.24198/JF.V15I1.11487

Amadi, J. A. C., Ihemeje, A., \& Afam-Anene, O. C. (2018). Nutrient and Phytochemical Composition of Jackfruit ( Artocarpus heterophyllus ) Pulp, Seeds and Leaves. International Journal of Innovative Food, Nutrition \&Sustainable Agriculture, 6(3), 27-32. www.seahipaj.org

Asih, S. W. (2018). Pengaruh Rebusan Daun Salam Terhadap Penurunan Tekanan Darah Pada Lansia Penderita Hipertensi Di Wisma Seruni Upt Pslu Jember. The Indonesian Journal of Health Science, $O(0)$, 169. https://doi.org/10.32528/ijhs.v0i0.1543

Bankar, G. R., Nayak, P. G., Bansal, P., Paul, P., Pai, K. S. R., Singla, R. K., \& Bhat, V. G. (2011). Vasorelaxant and antihypertensive effect of Cocos nucifera Linn. endocarp on isolated rat thoracic aorta and DOCA salt-induced hypertensive rats. Journal of
Ethnopharmacology, 134(1), 50-54. https://doi.org/10.1016/j.jep.2010.11.047

Bernard, H. R. (2002). Research methods in anthropology Qualitative and quantitative approaches (3rd ed.). Walnut Creek, CA Altamira Press. https://www.scirp.org/(S(i43dyn45teexjx $455 \mathrm{ql}$ 13d2q))/reference/ReferencesPapers .aspx?ReferenceID $=1017834$

Bhasin, V. (2007). Medical Anthropology: A Review. Studies on Ethno-Medicine, 1(1), $1-20$. https://doi.org/10.1080/09735070.2007.1 1886296

Carolia, N., \& Ghaisani, U. M. (2016). Psidium guajava sebagai Antihipertensi dan Antihiperlipidemia: Efek pada Penurunan Tekanan Darah dan Pengontrol Profil Lipid. In Jurnal Majority (Vol. 5, Issue 1). https://juke.kedokteran.unila.ac.id/index. php/majority/article/view/993

Chekole, G. (2017). Ethnobotanical study of medicinal plants used against human ailments in Gubalafto District, Northern Ethiopia. Journal of Ethnobiology and Ethnomedicine, 13(1), 1-29. https://doi.org/10.1186/s13002-0170182-7

Cheong, B. E., Zakaria, A., Ying, A., Cheng, F., Peik, \&, \& Teoh, L. (2016). GC-MS Analysis of Strobilanthes crispus Plants and Callus. Transactions on Science and Technology, 3(2), 155-161. http://transectscience.org/

Chrysant, S. G., \& Chrysant, G. S. (2017). Herbs Used for the Treatment of Hypertension and their Mechanism of Action. Current Hypertension Reports, 19(9). https://doi.org/10.1007/s11906017-0775-5

Dafriani, P. (2016). Pengaruh Rebusan Daun Salam (Syzigium Polyanthum Wight Walp) terhadap Tekanan Darah Pasien Hipertensi di Sungai Bungkal, Kerinci 2016. Jurnal Kesehatan Medika Saintika, 7(2), 25-34.

Daval, N. (2009). Consevation and Cultivation of Ethnomedicinal Plants in Jharkhand. in: Trivedi, P.C. Medicinal Plants Utilisation and Conservation.

Fabricant, D. S., \& Farnsworth, N. R. (2001). The value of plants used in traditional 
medicine for drug discovery. Environmental Health Perspectives, 109(SUPPL. 1), 69-75. https://doi.org/10.1289/ehp.01109s169

Gusti, N., Made, A., \& Farmasi, P. (2018). Kajian Penggunaan Obat Tradisional Sebagai Komplementer Dalam Pengobatan Hipertensi Di Universitas Surabaya. CALYPTRA, 7(1), 806-823. https://journal.ubaya.ac.id/index.php/jim us/article/view/1198

Handayani, L. (2003). Agromedia $\mid$ Membedah Rahasia Ramuan Madura - Agromedia. AgroMedia Pustaka. https://agromedia.net/katalog/membedah -rahasia-ramuan-madura/

Hasimun, P., Sulaeman, A., \& Maharani, I. D. P. (2020). Supplementation of Carica papaya Leaves (Carica papaya L.) in Nori preparation Reduced Blood Pressure and Arterial Stiffness on Hypertensive Animal Model. Journal of Young Pharmacists, 12(1), 63-66. https://doi.org/10.5530/jyp.2020.12.12

Hoe, S. Z., Kamaruddin, M. Y., \& Lam, S. K. (2007). Inhibition of angiotensinconverting enzyme activity by a partially purified fraction of Gynura procumbens in spontaneously hypertensive rats. Medical Principles and Practice, 16(3), 203-208.

https://doi.org/10.1159/000100391

Huang, W. Y., Davidge, S. T., \& Wu, J. (2013). Bioactive Natural Constituents from Food Sources-Potential Use in Hypertension Prevention and Treatment. In Critical Reviews in Food Science and Nutrition (Vol. 53, Issue 6, pp. 615-630). Crit Rev Food Sci Nutr. https://doi.org/10.1080/10408398.2010.5 50071

Iskandar, Y. (2007). Tanaman Obat yang Berkhasiat Sebagai Anti hipertensi. Universitas Padjajaran.

Kasumayanti, E., \& Putri, E. Y. (2018). Pengaruh Konsumsi Ekstrak Biji Mahoni terhadap Tekanan Darah pada Penderita Hipertensi di Desa Pulau Jambu Wilayah Kerja Pukesmas Kuok Tahun 2018. Jurnal Ners, 2(2). http://journal.universitaspahlawan.ac.id/i ndex.php/ners

Kumar, R., Kumar, R., \& Bharati, K. A.
(2014). Ethnomedicines of Tharu Tribes of Dudhwa National Park, India. Ethnobotany Research and Applications, 12(0), 001-013. http://ethnobotanyjournal.org/index.php/ era/article/view/848

Lima, E. B. C., Sousa, C. N. S., Meneses, L. N., Ximenes, N. C., Santos Júnior, M. A., Vasconcelos, G. S., Lima, N. B. C., Patrocínio, M. C. A., Macedo, D., \& Vasconcelos, S. M. M. (2015). Cocos nucifera (L.) (arecaceae): A phytochemical and pharmacological review. In Brazilian Journal of Medical and Biological Research (Vol. 48, Issue 11, pp. 953-964). Associacao Brasileira de Divulgacao Cientifica. https://doi.org/10.1590/1414$431 \times 20154773$

Maryadi. (2012). Studi Etnobotani Tumbuhan Obat Di Desa Seriang Kecamatan Bedau Kabupaten Kapuas Hulu. Universitas Tanjung Pura.

Melamba, B. (2019). Sejarah Etnomedisin Pada Suku Moronene. Prosiding Seminar Nasional Pengembangan Kajian Etnomedisin Dalam Memperkuat Karakter Generasi Muda, 27-35.

Moelyono. (2014). Buku Etnofarmasi. Penerbit Buku Pendidikan Deepublish. https://penerbitbukudeepublish.com/shop /buku-etnofarmasi/

Mujahid, R., Wahyono, S., Priyambodo, W. J., \& Subositi, D. (2019). Studi etnomedicine pengobatan luka terbuka dan sakit kulit pada beberapa etnis di Provinsi Kalimantan Timur. Kartika: Jurnal Ilmiah Farmasi, 7(1), 27. https://doi.org/10.26874/kjif.v7i1.178

Mulyani, S., Rosa, M., \& Huriah, T. (2015). Pengaruh Ekstrak Daun Belimbing Wuluh (Averrhoa Bilimbi L.) Terhadap Penurunan Tekanan Darah Tikus Putih Jantan (Rattus Norvegicus) Hipertensi. IJNP (Indonesian Journal of Nursing Practices), 1(2), 177-184. https://doi.org/10.18196/IJNP.V1I2.658

Odubanjo, V., Oboh, G., \& Makinde, A. (2016). Inhibitory Effect of Aqueuos Extracts of Avocado Pear (Persea americana) Leaf and Seed on Angiotensin 1- Converting Enzyme: A Possible Means in Treating/Managing Hypertension. 
Journal of Applied Life Sciences International, 4(1), 1-9. https://doi.org/10.9734/jalsi/2016/21605

Onyema-iloh, O., Meludu, S., Iloh, E., Dioka, C., \& Obi-Ezeani, C. (2018). Effects of Methanolic Extract of Vernonia amygdalina on Electrolytes and Renal Biomarkers in $\mathrm{NaCl}-$ Induced Hypertensive Male Wistar Rats. Journal of Pharmaceutical Research International, 23(1), 1-7. https://doi.org/10.9734/jpri/2018/41908

Paul, S., Devi, N., \& Sarma, G. C. (2013). Ethnobotanical Utilization Of Some Medicinal Plants By Bodo People Of Manas Biosphere Reserve In The Treatment Of Malaria. INTERNATIONAL RESEARCH JOURNAL OF PHARMACY, 4(6), 102-105. https://doi.org/10.7897/2230-8407.04622

Purwono, J., Sari, R., Ratnasari, A., Budianto, A., Dharma Wacana Metro, A. K., Muhammdiyah, U., \& Lampung, P. (2020). Pola Konsumsi Garam Dengan Kejadian Hipertensi Pada Lansia. Jurnal Wacana Kesehatan, 5(1), 531-542. https://jurnal.akperdharmawacana.ac.id/i ndex.php/wacana/article/view/120

Putri, D. A., \& Fatmawati, S. (2019). Metabolit sekunder dari Muntingia calabura dan bioaktivitasnya. ALCHEMY Jurnal Penelitian Kimia, 15(1), 57. https://doi.org/10.20961/alchemy.15.1.23 362.57-78

Qurthoniah, E. D. (2018). Etnomedisin Tumbuhan Obat Untuk Mengobati Penyakit Darah Tinggi (Hipertensi) Di Kecamatan Solokan Jeruk Kabupaten Bandung. http://fkip.unpas.ac.id/

Raharjo, S., Bandong, G. M., Tien, T., Syarif, A. N. K., Chahyadi, A., \& Aritrina, P. (2020). Pengaruh Ekstrak Bawang Putih Terhadap Kadar Serum Kreatinin Tikus Hipertensi Two Kidney One Clipp (Effect of Allium sativum Extract to Serum Creatinine of Two Kidney One Clipp Hypertension Rat). MEDULA, 7(1). https://doi.org/10.46496/medula.v7i1.11 831

Ranasinghe, R. A. S. N., Maduwanthi, S. D. T., \& Marapana, R. A. U. J. (2019). Nutritional and Health Benefits of Jackfruit (Artocarpus heterophyllus
Lam.): A Review. In International Journal of Food Science (Vol. 2019). Hindawi

Limited. https://doi.org/10.1155/2019/4327183

Riset Kesehatan Dasar. (2018). Hasil Utama RISKESDAS 2018.

Sahidin. (2019). Prospek Pengembangan Tanaman Obat Tradisional di Sulawesi Tenggara. Prosiding Seminar Nasioanal Pengembangan Kajian Etnomedisin Dalam Memperkuat Karakter Generasi Muda, 6-10.

Santana, L. F., Inada, A. C., Santo, B. L. S. do E., Filiú, W. F. O., Pott, A., Alves, F. M., Guimarães, R. de C. A., Freitas, K. de C., \& Hiane, P. A. (2019). Nutraceutical potential of carica papaya in metabolic syndrome. In Nutrients (Vol. 11, Issue 7). MDPI

AG. https://doi.org/10.3390/nu11071608

Sapei, A., Yanuar Purwanto, M. J., \& Kurniawan, A. (2011). Desain Instalasi Pengolah Limbah Wc Komunal Masyarakat Pinggir Sungai Desa Lingkar Kampus (Waste Water Treatment Plant Design Of Taile Communal of The Community Surrounding The Campus). In Jurnal Ilmu Pertanian Indonesia (Vol. 16, Issue 2). https://journal.ipb.ac.id/index.php/JIPI/ar ticle/view/6454

Shokoohinia, Y., Jafari, F., Mohammadi, Z., Bazvandi, L., Hosseinzadeh, L., Chow, N., Bhattacharyya, P., Farzaei, M. H., Farooqi, A. A., Nabavi, S. M., Yerer, M. B., \& Bishayee, A. (2018). Potential Anticancer Properties of Osthol: A Comprehensive Mechanistic Review. Nutrients, 10(1). https://doi.org/10.3390/nu10010036

Siddesha, J. M., Angaswamy, N., \& Vishwanath, B. S. (2011). Phytochemical screening and evaluation of invitro angiotensin-converting enzyme inhibitory activity of Artocarpus altilis leaf. Natural Product Research, 25(20), 1931-1940.

https://doi.org/10.1080/14786419.2010.4 97962

Van Wyk, M., \& Ben-Erik. (2004). Medicinal plants of the world: an illustrated scientific guide to important medicinal plants and their uses: Van Wyk, Ben-Erik; 
Wink, Michael: 9781875093441 : Amazon.com: Books. Timber Press. https://www.amazon.com/Medicinalplants-world-illustratedscientific/dp/1875093443

Wardenaar, E., \& Sisillia, L. (2015). Studi Etnobotani Tumbuhan Obat Oleh Etnis Suku Dayak Di Desa Kayu Tanam Kecamatan Mandor Kabupaten Landak. In JURNAL HUTAN LESTARI (Vol. 3, Issue 2). https://doi.org/10.26418/jhl.v3i2.10310

Wiliyanarti, P. F., \& Silaturrrohmih. (2020). citrifolia) Terhadap Penurunan. The Journal of Muhammadiyah Medical Laboratory Technologist, 3(1). https://core.ac.uk/download/pdf/3272638 55.pdf

Yadav, R. N. S., \& Agarwala, M. (2011). Phytochemical analysis of some medicinal plants. Journal of Phytology, 3(12 SE-Research Article). https://updatepublishing.com/journal/ind ex.php/jp/article/view/2737

Pengaruh Ekstrak Mengkudu (Morinda

Copyright (c) 2021 Jurnal Mandala Pharmacon Indonesia; This article is an open access article distributed under the terms and conditions of the Creative Commons Attribution License (http://creativecommons.org/licenses/by/4.0/) 